\title{
Factors that Influence the Choice of Business Major Evidence from Jordan
}

\author{
Dr Ahmad Nahar Al-Rfou \\ Department of Business Management Tafilah Technical University, Tafilah, Jordan Postal
}

\begin{abstract}
The purpose of this study is to examine the impact of personal factors and future job factors on choice of business as a major field of study. The study also aims to investigate the relationship between students' gender, general secondary average and the branch in general secondary, and the choice of business as a major, from the perspective of business students at Tafila Technical University (TTU) in academic year 2011/2012.

The study reached that the parents have a significant influence on the major selection, siblings and friends also consider important source to select the major, while the teachers and media are least amongst the selected factors. The respondents give more importance for future job factors; they agreed that the future earning, career option, occupational prestige and type of work are the most important factors that affect the selection of the business major. The results also, mentioned that there is a significant relationship between independent variables (i.e. gender, general secondary average and the branch in general secondary) and dependent variable (i.e. choice business as a major field of study).
\end{abstract}

Keywords: Academic Choice, Choice of Majors, Business Students, Tafila Technical University (TTU).

\section{Introduction}

Choosing a major is important decision in the person life because its effect in the study continuity, success or failure, satisfaction or dissatisfaction, and determine the job opportunity, appropriate financial return and social status, therefore, Beggs et .al (2008) define "good" major choice as the major best capable of helping the student to achieve their educational and post-education goals, they added the matching between the students' abilities and interest and the abilities required for the major is important in selection majors by undergraduate students.

Jordan has (10 )public universities, (17) private universities, and (51) community colleges, where the number of enrolled students in these institutions is estimated at nearly (236) thousand ; more than (60) thousand out of the total are business major (i.e. business management, accounting, finance, banking, economy, marketing and MIS) (Higher Education Ministry, 2012).

The increasing in business major students in Jordanian Universities over than the market capacity is questionable .Specifically, the students number in the TTU - which was established in 2005- has grown beyond all expectations and reached to (5914) students. Table (1) shows that the number of enrolled students in business major (1076) students which represent about (18\%) from university students. About $31 \%$ of the business majors fall in the accounting, $17 \%$ in business management, $32 \%$ in the financing \&banking, and $21 \%$ in the business economy.

Table1: Business Students Specializations

\begin{tabular}{|l|l|l|l|l|l|}
\hline & Accounting & $\begin{array}{l}\text { Business } \\
\text { management }\end{array}$ & $\begin{array}{l}\text { Financing } \\
\text { \&banking }\end{array}$ & $\begin{array}{l}\text { Business } \\
\text { Economy }\end{array}$ & Total \\
\hline No & 329 & 183 & 339 & 225 & 1076 \\
\hline \% & $31 \%$ & $17 \%$ & $32 \%$ & $21 \%$ & $100 \%$ \\
\hline
\end{tabular}

Source: - TTU, Admission and Registration Dept, 2012 at TTU?

The big question here is that what are the main factors that influence the choice of a business major

Previous studies (e.g. Malgwi, et al. 2005; DeMarie \& Young .2003; Pearson \& Dellman .1997; Lowe \& Simons 1997) examined many factors that play a vital role in the selection of business major. These factors (e.g. Career option, the interest in the area, enjoyment of learning, teachers, siblings, friends, media, and future earnings).

Kim et al. (2002) reported that business students rated interest in the field as the most important factor when choosing a major, above monetary compensation and job opportunity.

Against this background, this study aims to examine the impact of personal factors (i.e. Media, parents, teachers, friends and siblings) and the future job factors (i.e. Future earnings, career option, occupational prestige and type of work) on business major choice. The study also investigates the relationship between student's gender, 
general secondary average and the branch in general secondary, and the choice of business as major field of study, from the perspective of business students at TTU.

\section{Theoretical development and hypotheses formulation}

Choosing business as a major represents one of the most important decisions in person life, previous studies in this field searched the factors impact and influence students' decision. Malgwi, et al. (2005) defined the factors influencing the choice of a major (i.e. Interest in the subject, job opportunities, compensation, introductory course, and discussion with other students). Pearson and Dellman-Jenkins (1997) mentioned that about 19 percent of incoming freshmen stated that parents were the most significant factor influencing which major to pursue. These students also indicated that teachers were the second most influential. The importance of siblings, friends, and the media combined was less than that of parents. Recently, a number of studies have been conducted examining the selection of business as a major. Another study carried out by Uyar, et al. (2011) found that the students who have a desire to work in accounting field assume that accounting field provides good job opportunities, and the field matches with their abilities and interests. While, students who have no desire to work in the field of accounting assume that other fields provide wider job opportunities and are less stressful, tiring, and tedious. The study conducted by Worthington \& Higgs (2003) examined the role of student characteristics, personality, and perceptions of the banking and finance profession in determining the choice of an undergraduate finance major.

DeMarie and Aloise- Young (2003) found that the reasons for selecting a major for the business students are: career, the interest in the area, and enjoyment of learning.). Kim et al. (2002) determined the reasons for choosing a major which are: interest in a career associated with the major, good job opportunities, "good fit" with respondents' abilities, a desire to run a business some day, and projected earnings in the related career.

Lowe and Simons (1997) mentioned that the most factors influencing the choice of major business are earnings, career options, initial earnings, and ability/aptitude. Also found that the referents sources (i.e. parents, teachers) had only moderate influence on the major selected. Collins and Giordani (2004) reported that $68.4 \%$ of the respondents chose their major because they liked the kind of work it would enable them to do as compared to $7 \%$ who picked their major for its earning potential.

However, the above mentioned studies revealed mixed results. The importance of the current study comes from that it, to the best of my knowledge, is that the first study searched the relationship between factors (i.e. Gender, general secondary average and the branch in general secondary) and the choice of business as major field of study at (TTU).

Accordingly, the following hypotheses were developed:

H1: The gender contributes significantly toward the choice of the business study field.

H2: The general secondary average contributes significantly toward the choice of the business study field.

H3: The branch in general secondary contributes significantly toward the choice of the business study field.

\subsection{Sample selection and data collection}

\section{Methodology}

This study was designed to investigate the relationship between independent variables (i.e. Gender, general secondary average and specialization in general secondary) and selection business as a major , and also explore the impact of personnel sources of information and influence (i.e. Media, parents, teachers, friends and siblings ), and the future job characteristics (i.e. Future earnings, career option, occupational prestige, and type of work ) on the selection of business as a major, from the perspective of business students at TTU.

The population of study consists of all business students (1076) at TTU in academic year 2011/2012. 200 questionnaires were distributed.180 questionnaires were collected yielding a response rate of $90 \%$. The questionnaire was developed based on the previous studies. The questionnaire consisted of three parts: Part 1 is the demographic data and which include questions related to the respondents' demographic profiles. Part 2 (students' opinion) had questions measure the personnel factors that influence on selection the business major. Part 3 (students' opinion) had questions related to job characteristics. Data were analyzed by using the Statistical Package for Social Science (SPSS) version 16 software.

\subsection{Study variables}

1. Independent variables consist of :

-Student gender. (Male, female ).Table (2) shows that the female represent 50\% from total business students and the percentages between male and female are equal in all business majors .

- Branches in general secondary which are :( i.e. Literary, Shari'a , Scientific, Vocational, and Information management).

- $\quad$ General secondary average. (I.e. Excellent 90 or more, very good 80- 89, good 70-79, moderate 60-69). 
2. Dependent variable (major business) consists of: business management, accounting, finance \& banking, and business economy.

Table 2: Gender of students

\begin{tabular}{|l|l|l|l|l|l|l|l|l|l|l|}
\hline \multicolumn{2}{|l|}{ Business Majors } \\
\hline Gender & $\begin{array}{l}\text { Business } \\
\text { Management }\end{array}$ & $\%$ & Accounting & $\%$ & $\begin{array}{l}\text { Finance } \\
\text { Banking }\end{array}$ & $\%$ & $\begin{array}{l}\text { Business } \\
\text { Economy }\end{array}$ & $\%$ & Total & $\%$ \\
\hline Male & 76 & $42 \%$ & 175 & $53 \%$ & 155 & $46 \%$ & 129 & $57 \%$ & 535 & $50 \%$ \\
\hline Female & 107 & $58 \%$ & 154 & $47 \%$ & 184 & $54 \%$ & 96 & $43 \%$ & 541 & $50 \%$ \\
\hline Total & 183 & $100 \%$ & 329 & $100 \%$ & 339 & $100 \%$ & 225 & $100 \%$ & 1076 & $100 \%$ \\
\hline
\end{tabular}

Source: - TTU Admission and Registration Dept, 2012

\subsection{Descriptive analysis}

\section{Results and Discussions}

The data collected were processed through the study instrument using the SPSS program, where Simple regression analysis was used, in order to examine the relation between the study variables.

The students asked how much their choice of business major ((i.e. Business management, accounting, business economy, and finance $\&$ banking) was influenced by personal factors (i.e. Media, parents, teachers, friends and siblings), and future job factors (i.e. Future earnings, career option, occupational prestige and type of work).

On based on a 5-point Likret-scale with $1=$ no influence and 5 very influential .Table (3) shows the personnel sources of influence in the major selection. The respondents mentioned that the parents have a significant influence on the major selection, this result is not interesting in the society still believe that the parents play vital role in the socialization. Also siblings and friends consider important source to select the major, while the teachers and media are least influential. The respondents agree that the personnel influences on selection the business major with mean 3.05

Table 3: Personnel factor that affect the major selection

\begin{tabular}{|c|c|c|c|c|c|c|c|c|c|}
\hline & & 5 & 4 & 3 & 2 & 1 & \multirow[b]{2}{*}{ Mean } & \multirow[b]{2}{*}{ SD } & \multirow[b]{2}{*}{ Rank } \\
\hline & Factors & $\begin{array}{l}\text { Very } \\
\text { influential }\end{array}$ & $\begin{array}{l}\text { Somewhat } \\
\text { influential }\end{array}$ & Neutral & $\begin{array}{l}\text { Not very } \\
\text { influential }\end{array}$ & $\begin{array}{l}\text { No } \\
\text { influence }\end{array}$ & & & \\
\hline & Media & 20 & 25 & 10 & 60 & 65 & 2.31 & 0.211 & 5 \\
\hline & Parents & 82 & 59 & 6 & 15 & 18 & 3.96 & 0.584 & 1 \\
\hline \multirow{3}{*}{$\begin{array}{l}\overrightarrow{0} \\
\vec{g} \\
\overrightarrow{0} \\
\stackrel{0}{\tilde{E}}\end{array}$} & Teachers & 22 & 35 & 9 & 55 & 59 & 2.48 & 0.002 & 4 \\
\hline & Friends & 39 & 46 & 15 & 42 & 36 & 3.02 & 0.012 & 3 \\
\hline & Siblings & 63 & 49 & 15 & 23 & 30 & 3.51 & 0.325 & 2 \\
\hline \multicolumn{2}{|c|}{ Total } & & & & & & 3.05 & 0.23 & \\
\hline
\end{tabular}

To investigate the effect of future job on the choice of the business major, Table 4 illustrates that the respondents give more importance for future job factors than the personnel relation factors in selection business major. They agreed that the future earning, career option, occupational prestige and type of work are the most influence on selection of the major, with mean of $3.97,3.88$ and 3.57 respectively.

Table 4: Future Job Factors that affect the major selection

\begin{tabular}{|c|c|c|c|c|c|c|c|c|c|}
\hline \multirow{6}{*}{ 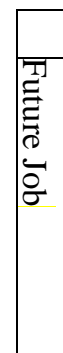 } & \multirow[b]{2}{*}{ Factors } & 5 & 4 & 3 & 2 & 1 & \multirow[b]{2}{*}{ Mean } & \multirow[b]{2}{*}{ SD } & \multirow[b]{2}{*}{$\begin{array}{l}\text { Ran } \\
k\end{array}$} \\
\hline & & $\begin{array}{l}\text { Very } \\
\text { influential }\end{array}$ & $\begin{array}{l}\text { Somewhat } \\
\text { influential }\end{array}$ & Neutral & $\begin{array}{l}\text { Not very } \\
\text { Influential }\end{array}$ & $\begin{array}{l}\text { No } \\
\text { influence }\end{array}$ & & & \\
\hline & Future earnings & 80 & 55 & 17 & 16 & 12 & 3.97 & 0.02 & 1 \\
\hline & Career option & 68 & 73 & 6 & 15 & 18 & 3.88 & 0.12 & 2 \\
\hline & $\begin{array}{l}\text { Occupational } \\
\text { prestige }\end{array}$ & 55 & 61 & 15 & 30 & 19 & 3.57 & 0.02 & 3 \\
\hline & Type of work & 44 & 49 & 17 & 37 & 33 & 3.19 & 0.01 & 4 \\
\hline \multicolumn{2}{|c|}{ Total } & & & & & & 3.65 & 0.04 & \\
\hline
\end{tabular}




\subsection{Hypotheses Test}

Table 5 shows that the result of liner simple regression indicates that there is a significant relationship between gender and the choice business as a major field of study (Beta=0.114., $\mathrm{p}=0.000$ ).

Table 5: Simple regression analysis, independent variable (gender) and dependent variable (business major)

\begin{tabular}{|l|l|l|l|}
\hline Independent & Beta & T & Significant \\
\hline Gender & 0.114 & $* 1.768$ & 0.000 \\
\hline
\end{tabular}

* Significant $(\alpha \leq 0.005)$

Table 6 shows the result of liner simple regression indicates that there is a significant relationship between general secondary average and the choice business as a major field of study (Beta=0.387., $\mathrm{p}=0.000$ ).

Table 6: Simple regression analysis, independent variable (general secondary average) and dependent variable (business major)

\begin{tabular}{|l|l|l|l|}
\hline Independent & Beta & T & Significant \\
\hline General secondary average & 0.387 & $* 2.653$ & 0.000 \\
\hline
\end{tabular}

* Significant $(\alpha \leq 0.005)$

Table 7 shows the result of liner simple regression which indicates that there is a significant relationship between the branch in general secondary and the choice of business as a major field of study (Beta= 0.297., $\mathrm{p}=$ 0.000).The previous studies supported this result, Taylor Report (2000) stated that compared to college students in general, accounting majors are more likely to be female. Leppel et al. (2001) found that female students are less likely to major in business; while the males are opposite. Lowe \& Simons (1997) found that female accounting majors ranked more important than did male accounting majors.

Table 7: Simple regression analysis, independent variable (specialization in general secondary) and dependent variable (business major)

\begin{tabular}{|l|c|l|l|}
\hline Independent & Beta & T & Significant \\
\hline Specialization in general secondary & 0.297 & $* 3.978$ & 0.000 \\
\hline
\end{tabular}

* Significant $(\alpha \leq 0.005)$

\section{Conclusions}

Selection the major in undergraduate stage is considered an important decision in the person life. Many scholars explored the factors that may influence the business major selection. The purpose of this study is to examine the impact of personal factors and future job factors on business major choice. The study also aims to investigate the relationship between students' gender, general secondary average and the branch in general secondary, and the choice of business as major field of study, from the perspective of business students at TTU in academic year 2011/2012.

The study explored that the parents have a significant influence on the major selection, siblings and friends also consider important source to select the major, while the teachers and media are the least amongst the selected factors. The respondents give more importance for future job factors; they agreed that the future earning, career option, occupational prestige and type of work are the most important factors in selecting the major. The results also indicated that there is a significant relationship between independent variables (i.e. gender, general secondary average and the branch in general secondary) and dependent variable (i.e. selection business as a major).

Based on the above mentioned results, the study recommends considerable amendments on the admission policy in Jordanian universities, to match between the students' abilities and the major, and awareness the students with majors and future job opportunities. This study has opened doors for many future research opportunities in the Jordanian environment. These include for example taking many other variables such as the policies of admission in Jordanian universities.

\section{References}

[1] Beggs, J. M., Bantham, J. H., \& Taylor, S. (2008).Distinguishing the factors influencing college students' choice of major. College Student Journal.

[2] Collins, M. and P. Giordani. (2004).The class of 2003: Opinions and expectations results of the 2003 graduating student and alumni survey. NACEWeb, http://naceweb.org

[3] DeMarie, D., \& Aloise-Young, P. (2003). College students' interest in their major. College Student Journal, 37, 462-470. 
[4] Higher Education Ministry. (2012). Brief on Higher Education Sector in Jordan, http://www.mohe.gov.jo/brief/briefMohe1/tabid/558/language/en-US/Default.as retrieved 10/12/2012

[5] Kim, D., Markham, F., \& Cangelosi, J. (2002). Why students pursue the business degree: A comparison of business majors across universities. Journal of Education for Business, 78, 28-32.

[6] Leppel, K., Williams, M. L., and Waldauer, C. (2001). The impact of parental occupation and socioeconomic status on choice of college major. Journal of Family and Economic issues, 22, 373-394.

[7] Lowe, D. R.,Simons, K. (1997). Factors influencing choice of business majors - some additional evidence: a research note. Accounting Education: An International Journal, 6, 39-45.

[8] Malgwi, C., Howe, M., \& Burnaby, P. (2005). Influences on students' choice of college major. Journal of Education for Business, 80, 275-282.

[9] Pearson, C., \& Dellman-Jenkins, M. (1997). Parental influence on a student's selectionof a college major. College Student Journal, 31, 301-314.

[10] Taylor Research and Consulting Group, Inc. (2000). AICPA Student and Academic Research Study-Final Quantitative Report.

[11] TTU, Admission and Registration Dept (2012). Annual report for admission and registration department.

[12] Worthington, Andrew and Higgs, Helen (2003) Factors explaining the choice of finance major: the role of student characteristics, personality and perceptions of the profession. Accounting Education 12(3):pp. 261-281

[13] Uyar, A. Güngörmüş, A, Kuzey, C. (2011). Factors Affecting Students' Career Choice in Accounting: The Case of a Turkish University. American Journal of Business Education - October 2011 Volume 4, Number 10 p.29. 